\title{
Study on the Problems and Solutions of Public Prosecution in Courts in China
}

\author{
Qiong Zhang \\ Hunan Judicial Police Vocational College \\ Changsha, China 410131
}

\begin{abstract}
This paper discusses the present situation and existing problems of public prosecution in courts in China from its importance, and analyzes how the prosecutor can improve the professional quality, psychological quality and language ability. It also discusses how to improve the relevant legal system by improving relevant legal system, reforming legal instruments, strengthening the management mechanism and standardizing the procedures of handling.
\end{abstract}

Keywords-public prosecutor; public prosecution in courts; problem; solution

\section{INTRODUCTION}

In recent years, due to various reasons, a considerable part of the prosecutors from grassroots procuratorate do not care public prosecution in courts and casually cope with it. There are less and less public prosecutors that really can get fully prepared before going to court, accurately use the evidence in court, and serious carry out cross-examination. The indifference to public prosecution in courts is specifically embodied in: they do not draw up the outline of testification or the outline of inquiry, and lack the pre-arranged plan of testification and cross-examination; they do not do their best for the testification and cross-examination of the defendant in the court; they do not review the relevant legal provisions and legal theory; they perform feebly in debate process and become formalistic, and some do not even write prosecution opinions or dress not according to the provisions. The indifferent attitude of the prosecution in courts has a very negative impact on the procuratorial organs' prosecution work, and it is necessary to analyze this phenomenon in order to correctly resolve.

\section{ANALYSIS ON THE REASON FOR PROBLEMS OF THE PROSECUTORS' PROSECUTION IN COURTS}

\section{A. The Sense of Responsibility Is not Strong, Indifferent to Prosecution in Courts}

Public prosecution work is hard, which takes a lot of trouble and effort, and needs strong will and hard work. Some prosecutors are not enthusiastic, and are often dragging and lazy in work. Their awareness of the effect and significance of the prosecution in courts is weakened, and they believe that the public security organs will investigate the case, the procuratorial organs will approve the arrest, the case will be transferred to the court for hearing after review and prosecution, the case has been reviewed and checked by many people, and they do not have to worry about the case, but the possibility for sentence of not guilty is very small, so they put the files on the shelf after prosecuting to the court, and become indifferent to prosecution in courts.

\section{B. There Are Few Court Lawyers, Lacking Prosecution Opponents}

In the stage of public prosecution in court, if there is a lawyer defending the defendant, the prosecutor will not only seriously prepare for the trial, but will do his/her best in testification and cross-examination, without any neglect. However, in recent years, for the defendant weakens the role of lawyers in court defense, and some lawyers charge unreasonably, there are not many cases in which the lawyer appear in court to defend, thus contributing to the prosecutors' indifference, and the prosecutors have no intention to improve the ability of defence against antidumping lawsuits.

\section{There Is Little Incentive Mechanism, Lacking Defense Power}

Some grassroots procuratorates, despite a series of plans to improve the level of public prosecutors they make, have always failed to realize them for the lack of funds. For cities and counties in economically underdeveloped central and western regions, local finance is still tight. In addition to guaranteeing the basic salary and basic benefits of police officers, there is no extra fund for the specialized training to improve the level of prosecutors, and the prosecution work need growing day by day cannot be met.

\section{Reason in Aspect of Selecting and Employing Personnel}

In China, the Civil Servant Law provides that the prosecutor is a special kind of civil servant, whose "morality, ability, diligency, performance and honesty" should be comprehensively assessed, with focus on assessment of work performance, as the basis for adjustment of duties, levels, wages and incentives, training and dismissal. It adheres to equal stress on integrity and ability, takes morality as first, forms the correct guide for selecting personnel, at the same time, it regulates the appointment and nomination system of cadres, improves the credibility space on the basis of the expansion of democracy, prevents the space of individual power operation, and strengthens the supervision on selecting 
and employing personnel, to improve the credibility of cadre management.

\section{Solution to PRoblems Related to Public PROSECUTION IN COURTS IN CHINA}

\section{A. Overcome the Prosecutors' Indifferent Attitude to Public Prosecution}

1) Raise awareness and enhance the prosecutors' sense of responsibility: Prosecution in court is an important duty that the people's procuratorates must perform in the trial stage of the prosecution case. The prosecutors must clarify their duties and tasks in court, that they represent the image of the procuratorial organs and exercise the duty of legal supervision.

2) Create conditions to enhance the prosecutors' selfconfidence: Organize police officers to sit in curt, carry out post training, encourage the defendant's close relatives and the masses to actively sit in the court to create the conditions of prosecution. Article 151 of the Criminal Procedure Law makes a clear provision: the condition for public trial, the cause of action, the defendant's name, court time and place are published three days before opening the court session.

3) Strengthen the measures to enhance the prosecutors' consciousness: The procuratorial organs must strengthen the measures to build the "window" of public prosecution, and establish a good image in the minds of the people. Cultivate a prosecutor team with socialist concept of rule by law, good moral character and fight ability, to overcome the prosecutors' indifference to prosecution in court.

4) Develop the correct values of prosecutors: The prosecutors' work involves the general public, affects the correct and uniform implementation of the law, and relates to social justice.

\section{B. The Overall Quality of Prosecutors Should Be Improved}

Firstly, the public prosecutors should have a solid professional quality. Solid business knowledge is the basis of the prosecutors to support the prosecution, and the prosecutor's good strategy psychological skill is built on familiarity with the case and solid legal knowledge.

Secondly, the prosecutor should have a good psychological quality. In order to achieve the best purpose of prosecution, prosecutors must make full psychological preparation before the prosecution, and have good psychological quality in the trial. The reformed criminal trial gives full play to the role of prosecution, defense and trial parties in criminal proceedings, and strengthens the prosecutor' role in trial charge and confirmation of crime. Therefore, more attention shall be paid to training of the prosecutors' psychological adaptability on the basis of education of necessary psychological knowledge, such as the organization of trial viewing, "match" and other activities.

Thirdly, the prosecutors should have sharp language skills. The prosecutor's performance in courts depends on their eloquence. Prosecutors express the true meaning of the language in court, so the language should be concise, practical, persuasive and shocking. The use of too many gorgeous words and long sentences shall be avoided, to prevent defenders from putting forward emotional factors or causing ambiguity in long sentences, and create opportunities for the defender to refute.

\section{Correctly Handle Various Relationships}

1) Correctly handle the relationship with the defenders: The prosecutors, as representatives of the state, stand on the standpoint of prosecuting the crime, which is determined by the litigation function assumed by the procuratorial organs. In contrast, the defenders, as vindicators of the defendant's interests, stand on the standpoint of maintaining the legitimate interests of the defendant, and defending innocence or misdemeanor according to the prosecutor's opinion is determined by the duty and work of the defender, therefore, the prosecutor have to uphold the charge of the indictment in the court, and also carefully listen to the views of the defenders.

2) Communicate the relationship between procuratorial organs and courts: In essence, prosecutors and defender are fully equal in litigation rights and the defender may consult and copy the evidentiary material submitted by the prosecutor to the court after the case is prosecuted to the court, while the prosecutor has no power to ask that the defender to open evidence. Because of the natural deficiency of legal provisions, the prosecutors can only understand the contents of information acquired by the defender through exchange of views of the case with the judge before the trial, and sometimes the procuratorial organ and court have difference in understanding of the facts of some cases or the relevant legal provisions, and the prosecutor can eliminate differences and unify understanding through the consultation with the judge before the trial. On the one hand, it closes the relationship between procuratorial organs and courts, on the other hand, it also enhances the prosecutors' confidence in public prosecution, and has an essential role in maintaining the unified and correct implementation of national laws and making up for omissions of the relevant legal provisions.

3) Deal with the relationship between the prosecutor and the lawyer: Prosecutors and lawyers are competing and opposing in court, but this does not affect their harmonious communication under court and proper communication before trial, which helps both sides understand the facts and applicable laws. Although the prosecutor and the defender pursue different purposes of litigation, both sides are to protect human rights, safeguard fairness and justice, and their ultimate pursuit is the same. Therefore, it is necessary for both sides to maintain the confrontation in court, which is also the proper meaning of the modern criminal procedure system, but they should also maintain the appropriate cooperation, which is also conducive to the maintenance of legal authority and the smooth conduct of the trial.

\section{Improve the Relevant Systems and Procedures}

Firstly, improve the relevant legal system. Specifically, it is to improve the court's funding system, the judge's personal 
responsibility system, and the procuratorate's reasonable protest system.

Secondly, reform the legal instruments. It is to make specific provisions for the signature upon receiving the legal documents, content requirements, written records and other aspects, to restrain the prosecutor, fix and evidence the prosecution content, and ensure that the court supports the substantive role of prosecution.

Thirdly, strengthen the management mechanism, and standardize the handling procedures.

Fourthly, increase the financial investment of grassroots procuratorates, enable the grassroots procuratorate to obtain appropriate funds and personnel protection.

\section{CONCLUSION}

Public prosecution work is the facade and window of prosecution business, to see the whole of the prosecution work through the prosecution work. The quality and effect of the prosecution not only relates to whether it can effectively expose, confirm and combat crime, and ensure the correct implementation of national laws, but also relates to the procuratorial organs' prestige and image among people.

At this stage, with the development of lawyer team, lawyers have reached a higher level in the identification of facts, the grasp of evidence, the study of jurisprudence, or the ability to debate. In strong contrast to the prosecution team which develops relatively slowly, these are the new issue and tests put forward by procuratorial organs, and prosecutors shall improve their own quality without delay.

\section{REFERENCES}

[1] Li Baoying: "On how to strengthen the prosecutor capacity building" [J]. Legal System and Society, 2008.26.

[2] "On the prosecutors' indifference in public prosecution in court" [J]. research article selection of Shaoyang City People's Procuratorate. 2010.1.

[3] People's Procuratorate of Dongguan City, Guangdong Province: "Three points of reflection on the prosecution" [N]. Procuratorial Daily. 2010.6

[4] Zhao Song, Li Wenfeng: "On the experience of court prosecution" [J]. Procuratorial View. 2010.6.

[5] Long Zongzhi, Yang Jianguang: "Criminal Procedure Law" [M]. Beijing: Higher Education Press, February 2007.

[6] Chen Guangzhong: "New exploration on litigation law" [M]. Beijing: China Legal Press, May 2000.

[7] Wang Kai, "On the prosecutors' psychology in public prosecution in court" [J]. Law Education. 2008.9.

[8] "The Code of Prosecutors' Conduct in Court of Supreme People's Procuratorate (Trial)" [M]. [December 10, 2004 (2004) GAO JIAN SU FA No. 107]

[9] Yang Yingze: "Practice of prosecutors in prosecution in court" [M]. Beijing: China Legal Publishing House, June, 2000, first edition.

[10] Chen Guangzhong: "Criminal Procedure Law (third edition)" [M]. Beijing: Higher Education Press, 2009 edition. 